REFLECTIONS:

NEUROLOGY AND THE

HUMANITIES

Section Editor

Michael H. Brooke, MD

\title{
The attic in the rue d'Ulm
}

Stuart Lubarsky, MD

Address correspondence and reprint requests to Dr. Stuart Lubarsky, Montreal

Neurological Institute, 3801 University Street, Montreal, Quebec, Canada H3A 2B4 stuloob@hotmail.com
There is a time in every man's life when he looks to his God, when he looks at his life, when he wonders how he will be remembered.

—Louis Pasteur

Rain sprayed the dark windows of the two-story house in the rue d'Ulm, Quartier Panthéon, Paris. It was approaching the end of October 1868, and a chill had seeped in through the floorboards. The gentleman sat quietly in his chair, his housecoat pulled tightly across his shoulders. Finally, he slipped from the room, careful not to disturb his slumbering wife.

The man- 45 years old, beard of black and meticulously trimmed, eyes of blue behind neat metal pincenez-could not sleep. His headache, worse than usual even for him, was not the source of his disquiet. And although the unusual spell he had experienced earlier that day had quite unsettled him and had nearly prevented him from giving his lecture to the Academy, it had by now escaped from his mind. Instead, it was a fervent intellectual energy, a sense of moment, that gripped him and caused him to abandon his bed. Once again, the man was on the threshold of discovery, and he knew it.

A safe distance down the corridor, he lit a braided candle. He hesitated at the base of the stairs, sensing their pull. It was a call to work, an appeal to the unflagging, industrious nature of a man whose mind would not rest. Cupping the flame with his left hand, he proceeded toward the attic.

Earlier that year, a mysterious plague had befallen the golden mulberry trees of the region. As a result, the economy was suffering, and the agriculturalists were baffled.

Desperate, the Minister of Agriculture and Commerce had presented the man with a challenge. His entreaty for help was calculated: He suspected that the man would not pass on the potential for further adulation in the eye of the public. He also believed that no one but this man could save the entire silk industry, the most prosperous and wealthy of the nation of France, from certain disaster.

The Minister was right in both regards.

The man's head ached. Once, when he was a boy, his father had counseled him to rub a few drops of cologne into his hair to prevent migraines. A skeptic even as a child, he had questioned the validity of this bit of medical wisdom. His father, irascible veteran of the Napoleonic wars, had rebuked him with vigor.

He closed the door quietly behind him. He paused for a moment, bathing in familiarity. His stoic demeanor belied the giddiness that he now felt so close to undiscovered truth.

From outside the window overlooking the garden, gas lamps spilled light onto bowed cabinets containing the eclectic tools of the man's trade: glass tubes, crystallizing pans, oil lamps, incubators, chalk, yeast, sugar, and wines from Burgundy, Bordeaux, and the Jura. Swan-necked flasks in neat rows dipped their heads like glass genuflectors. Alone in his laboratory, the man moved with an ease he did not enjoy in the company of men. He drew his stool closer to the polished oak table upon which rested his most treasured instrument: his microscope.

The problem before him was simple: The silkworms of France were dying, and no one could understand why. Even the healthiest specimens imported from Turkey and China were becoming disease-ridden after a short time among the French silkworm nurseries. The man had already received letters from many plaintive farmers and several angry government officials, whose livelihoods depended on his success in unraveling the silkworm mystery.

The project had been painstaking and maddeningly fraught with error. But the man's perseverance allowed him to curry success from setback. He had devised an experiment in which he fed one group of silkworms mulberry leaves smeared with the detritus of sick worms and a second group leaves containing the remains of worms that were healthy. For the next few months, he examined the two silkworm populations obsessively-at least several times daily and often, as on this occasion, in the small hours of the night. In his pursuit of scientific truth, work had become his raison d'être.

The attic was hot and smelled of ammonium. The throb in his head had escalated with the rain. In the dim light, he wearily collected another sample of silkworms and set them under the microscope. His suspicions continued to bear out: The worms fed on disease were becoming diseased, whereas those fed 
on uncontaminated leaves had remained healthy! He would thus be able to instruct farmers to distinguish normal silkworms from those that were sick and isolate them to a disease-free environment. With tenacity and scientific rigor, he had figured out how to save the French sericultural industry from ruin.

The imminent success of the silkworm study pleased him. But secretly it was another idea, an unprecedented thought, that crackled in his head like brushfire and kept him awake at night. It had taken rudimentary shape during his earlier studies on fermentation and had now blossomed into a theory with farther-reaching implications than even he, in all his intellectual arrogance, could imagine.

His pulse quickened as he considered the significance of the patterns of contagion he had observed in his study. If microbes were active agents of infection among silkworms, perhaps they were also conveyors of disease in man. Protective measures could therefore be envisioned-hand washing, boiling of water, and the heating of surgical instruments, to name a few-as a means to contain microbes and prevent the epidemic spread of disease. Mortal enemies such as cholera, yellow fever, and abscess would yield to simple sanitation practices.

Excitedly, the man pushed his thoughts further, giving them a momentum of their own. He recalled that an English physician named Jenner had once inoculated patients with vaccinia, infected material from cowpox sores he had scraped from the delicate arms of young milkmaids. All at once, the man understood with profound clarity the microbiologic basis of Jenner's findings. With this insight came a glimpse of disease prevention beyond even the methods of quarantine and antisepsis. His vision was the immunization of man against germ.

The floodgates of discovery had finally opened. The man's mind became inundated with a thousand new hypotheses and a thousand new experiments. He fumbled for a notebook and quill.

Then, in a flash of incalculable time, a sensation, the very same that he had felt and attributed to raw nerves earlier that day, overcame him. Once again, the prickling feeling materialized so abruptly and thoroughly on the left side of his body that it seemed to be a part of his fabric, as if it had existed within him forever. He stopped thinking, unsure what to do. He lifted his arm to inspect it, as if the answer lay there, like the microscopic spots on his silkworms. It felt leaden.

And then he was whole again. As suddenly as it had struck, the bizarre sensation in his left side vanished. He closed his eyes and curled his fingers into a tight ball, imprinting small crescent moons onto the flesh of his palm.
The air was still. Trembling, he gathered the writhing silkworms that were strewn across the table and hastily returned them to their breeding pens. He made every effort to remain silent. But when he began to collapse, he reflexively clutched at the closest object within reach. His microscope landed on the floor with a crash seemingly loud enough to wake the whole of France.

The room was dark. The night's rain left tearstreaks on the window, and the man's wife had drawn the shutters. She now sat by his side, kneading his limp hand, wishing it back to life.

Three doctors huddled at the bedside, conferring in hushed tones. At length one doctor placed his fingertips on the man's wrist.

"Will he get better?" asked the man's wife. Countless times throughout the night she had watched the strength ebb and flow from his body, cruel tides that, by morning, had finally receded and left him in his present condition.

"The left half of his body is paralyzed," said the eldest doctor evenly. "One cannot say for certain how much he will recover."

Suddenly the man's eyes opened. He fixed his gaze on the doctor's grave face. When he spoke, the words were slow and thick. "Am I able to work?"

His mouth formed an oblique slash on the lower half of his face.

"Reposez-vous, mon cher Monsieur. It is your time now to seek life's less demanding pleasures."

The man turned his head away from the doctor, away from his wife. "The only thing that can bring joy is work."

The doctor leaned forward. "Pardonnez-moi, Monsieur?"

"Merci, Docteur. Thank you."

The doctor took a last glance at the man's lopsided face. At the door he turned and held his palms outstretched, at once a gesture of reverence and helplessness. "It is my honor and my duty to serve at the pleasure of Monsieur Louis Pasteur."

The doctors exited the room, leaving husband and wife alone. He looked at her and wanted to tell her that he had succeeded in solving the silkworm mystery. He wanted to tell her that he had imagined a means to protect man and child from the ravages of infectious disease. He wanted to tell her that he feared his zeal had finally overcome him, had led to the cerebral apoplexy that now crippled him. He wanted to put his arms around her.

But for the first time in his life, the effort for action seemed too strenuous. Instead he lay silent, wondering if his opportunity for further contribution to science and medicine had seeped from his body like the vital force in his left side. 


\section{Neurology}

The attic in the rue d'Ulm

Stuart Lubarsky

Neurology 2007;68;1867-1868

DOI 10.1212/01.wnl.0000262776.39687.5c

This information is current as of May 21, 2007

\section{Updated Information \&} Services

Permissions \& Licensing

Reprints including high resolution figures, can be found at: http://n.neurology.org/content/68/21/1867.full

Information about reproducing this article in parts (figures,tables) or in its entirety can be found online at:

http://www.neurology.org/about/about_the_journal\#permissions

Information about ordering reprints can be found online:

http://n.neurology.org/subscribers/advertise

Neurology ${ }^{\circledR}$ is the official journal of the American Academy of Neurology. Published continuously since 1951, it is now a weekly with 48 issues per year. Copyright . All rights reserved. Print ISSN: 0028-3878. Online ISSN: 1526-632X.

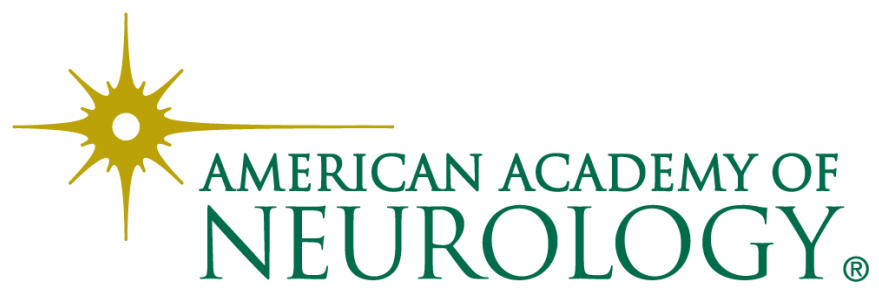

